\title{
Primary neuroendocrine tumor in a canine
}

\section{Tumor neuroendocrino primario en un canino}

BARRAGAN-CANO, Victor*†, ACERO-ORTEGA，Juanita，BAÑULLOS-PINEDA，Jacinto and LOEZA-CORICHI, María Eugenia

Universidad de Guadalajara. Departamento de Medicina Veterinaria, Centro Universitario de Ciencias Biológicas y Agropecuarias. Km 15.5 Carretera Guadalajara-Nogales, Las Agujas, Zapopan Jal.

ID $1^{\text {st }}$ Author: Victor, Barragan-Cano

ID $1^{\text {st }}$ Coauthor: Juanita, Acero-Ortega

ID $2^{\text {nd }}$ Coauthor: Jacinto, Bañuelos-Pineda

ID $3^{\text {rd }}$ Coauthor: María Eugenia, Loeza-Corichi

DOI: $10.35429 / E J R G .2019 .9 .5 .21 .25$

Received June 10, 2019; Accepted December 30, 2019

\begin{abstract}
The objective know the cause of death of the pet. Pulmonary neoplasms can arise from all parts of the lung, with a histological pattern. Tumors derived from the epithelium of the large airways are located near the lyle of the lung. The majority of canine tumors are adenocarcinomas and progressions from a bronchiolealveolar pattern to one of mucus-secreting glands or papillary growth. This case was presented, at the University of Guadalajara Animal Pathology Research Center, Canberman cadaver, female, 10 years old and weighing $19 \mathrm{~kg}$, the clinical history indicates that the animal had 12 days of bronchopneumonia; At necropsy he presented Lungs: Severe diffuse emphysema, moderate congestion, discrete diffuse thickening of the pleura and moderate edema, characteristic of the tumor, is classified as anaplasic small cell carcinoma fusiform type. Some lymph nodes have invasion of tumor cells of the lung. Small cell lung tumors are currently classified as neuroendocrine or carcinoid tumors. Their contribution sensitize animal owners so that they attend them on time, and have a better quality of life.
\end{abstract}

Neoplasia, Tumor, Lun

\begin{abstract}
Resumen
El objetivo saber la causa de muerte de la mascota. Las neoplasias pulmonares pueden surgir de todas las partes que componen el pulmón, con un patrón histológico. Los tumores derivados del epitelio de las vías respiratorias grandes son localizados cerca del hílio del pulmón. La mayoría de los tumores caninos son adenocarcinomas y progresiones de un patrón bronquiolo-alveolar a uno de glándulas secretoras de moco o de crecimiento papilar. Este caso se presento, en el Centro de Investigación en Patología Animal Universidad de Guadalajara, cadáver de canino, Doberman, hembra, de 10 años de edad y $19 \mathrm{~kg}$ de peso, la historia clínica refiere que el animal tenía 12 días padeciendo bronconeumonía; A la necropsia presentó Pulmones: Enfisema severo difuso, congestión moderada, engrosamiento discreto difuso de la pleura y edema moderado, características el tumor, se clasifica como carcinoma anaplásico de células pequeñas tipo fusiforme. Algunos linfonodos presentan invasión de células tumorales del pulmón. Los tumores pulmonares de células pequeñas se clasifican actualmente como tumores neuroendocrinos o carcinoides. $\mathrm{Su}$ contribución sensibilizar a dueños de animales para que los atiendan a tiempo, y tengan mejor calidad de vida.
\end{abstract}

Neoplasia, Tumor, Pulmón

Citation: BARRAGAN-CANO, Victor, ACERO-ORTEGA, Juanita, BAÑUELOS-PINEDA, Jacinto and LOEZACORICHI, María Eugenia. Primary neuroendocrine tumor in a canine. ECORFAN Journal-Republic of Guatemala. 2019, 59: $21-25$

\footnotetext{
* Correspondence to Author (email: victorbarragancano@ gmail.com)

$\dagger$ Researcher contributing first author.
} 


\section{Introduction}

Pulmonary neoplasms can arise from all the parts that make up the lung. Tumors of significant clinical incidence mostly arise from the epithelium of the airways or alveolar parenchyma. Several approaches for the classification of lung tumors, both in humans and animals, have used the site of origin (bronchogenic, bronchial or bronchioalveolar gland), histological pattern (adenoid, squamous, large cell, small cell) or combinations of these.

Unfortunately there is an overlap in the histological pattern of tumors from various sites of origin within the lung. Other complications arise because the site of origin is often being hidden, by the aggressive growth of the tumors when they are being examined and by the differentiation from one phenotype to another at various stages of the neoplastic process. The phenotype, therefore, is not a completely reliable indication for histogenesis (Wilson, 2017).

Tumors derived from the epithelium of the large airways are more frequently located near the lung's lung, while tumors of parenchymal origin tend to be peripheral. Although the increase in the incidence of tumors in both places is associated with cigarette smoking, peripheral lung tumors are more common in non-smokers (Wilson and Doungworth, 2002).

It has been thought that primary lung tumors in dogs arise from terminal bronchioalveolar regions. Most canine tumors are adenocarcinomas and progressions of a bronchio-alveolar pattern to one of mucussecreting or papillary growth glands that can often be discerned in different regions of the tumor. In addition, squamous differentiation in canine lung tumors is often evident as progression within glandular or solid carcinomas. There is no convincing evidence of small cell carcinomas in domestic animals and in the few tumors that express neuroendocrine markers they are better classified as carcinoids (Wilson, 2017).

With the exception of dogs and cats, lung malignancies are a rare finding in domestic animals (Ogilvie et al. 1989). The prevalence of lung cancer in cats seems to be the same or slightly higher than in dogs.
A review of case records submitted for pathological evaluation at the University of California found that lung neoplasm accounted for $0.75 \%$ of feline cases, compared with $0.58 \%$ of all canine cases (D, Costa et al., 2012 ). The reported average age of dogs with primary lung tumors in several studies in the last four decades is consistent with an average of 10.8 years, lung tumors are rare in dogs under 6 years (Choi et al. 2008).

Although they are still rare, neuroendocrine-like cell tumors occur in dogs and are diagnosed as neuroendocrine or carcinoid tumors. They are characterized by their histological similarity with neuroendocrine growths with round to polygonal cells, grouped into small solid aggregates by thin fibrovascular stroma. The neoplastic cells have regular size, spherical and central nucleus, their cytoplasm is modest and slightly amphophilic. They are positive for chromogranin A. It is proposed that these tumors arise from neuroendocrine cells of the airway epithelium, although immunohistochemical stains for markers such as the bombesin and calcitonin peptide regulatory gene are negative and electron microscopy has not been done to demonstrate intracytoplasmic granules (Harkema et al., 1992).

\section{Clinical case description}

The carcass of a canine, Doberman breed, female, 10 years old and $19 \mathrm{~kg}$ in weight, with a medical history that indicates that the animal was presented for necropsy, at the Center for Research in Animal Pathology at the University of Guadalajara I had 12 days suffering from bronchopneumonia; It also refers that the animal had its complete vaccination and deworming chart, that it lived with 2 cats and that it was fed only with croquettes and tap water.

I applied as initial treatment amoxacillin + clavulanic acid, ambroxol and nimesulide; then he was exchanged for enroflaxacin and liquid bisolbon, and finally he was finished supplying lincomycin, dexamethasone and salbutamol. None of the above medications specified the dose, frequency or duration of treatment. It is also mentioned that the owner is an active smoker who smoked in the presence of the canine. 
The findings found at the autopsy were:

External inspection: Bad, conjunctive, oral and vulvar mucous condition with moderate congestion, discreet presence of tartar in dental pieces.

Internal inspection: Hydrothorax and moderate hydropericardium.

Lymph nodes: Submandibular and subscapularis enlarged, severe congestion. Spleen: Moderately diffuse pale.

Trachea, and bronchi: Discreet presence of bloody mucus in the light.

Lungs: Diffuse severe emphysema, moderate congestion, diffuse diffuse thickening of the pleura and moderate edema. Presence of tumors, one of them is observed on the dorsal surface of the right cranial lobe, with an oval shape of $8 \times 3 \mathrm{~cm}$, well defined, soft consistency, pus and a reddish coloration are observed at the cut. Others are located in the branches of the bronchi, causing severe thickening of the wall of the bronchi, with little defined delimitation, firm consistency and the cut is reddish white.

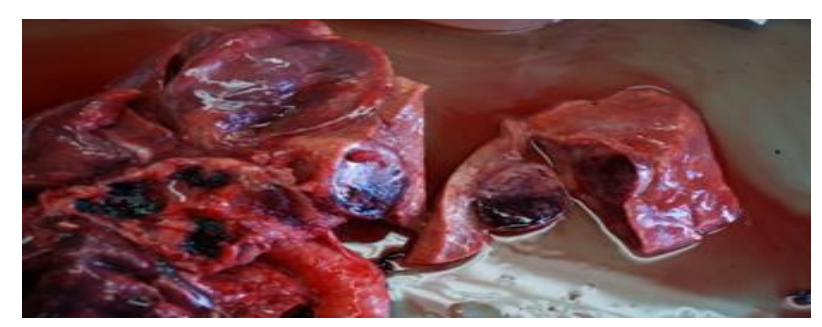

Figure 1

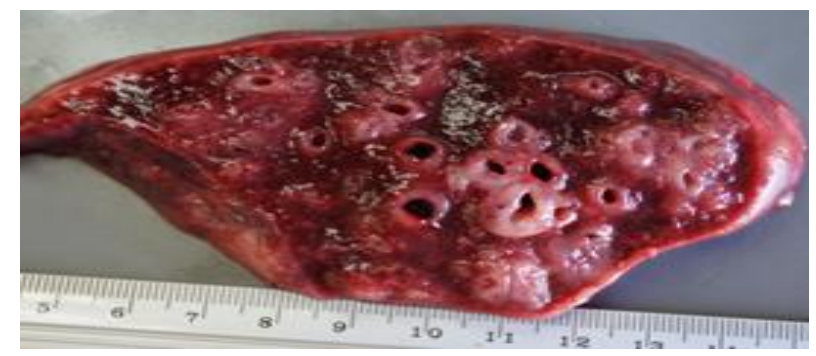

Figure 2

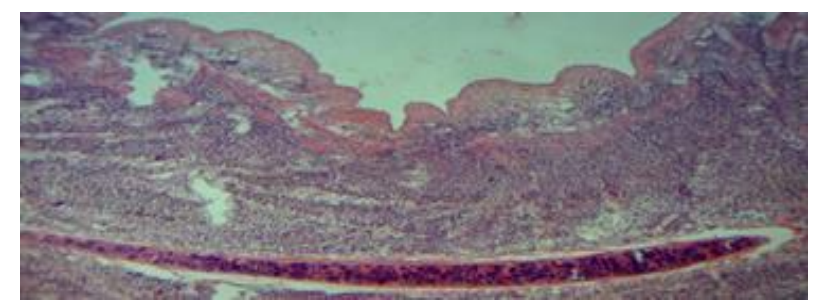

Figure 3

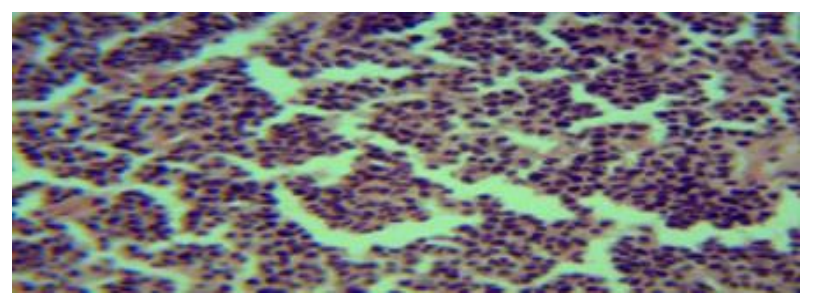

Figure 4

Heart: Discreet dilatation of the right ventricle, discrete congestion, bicuspid valve with discrete endocardiosis and discrete hemorrhage.

Esophagus: Moderate diffuse
congestion.

Stomach: Containing yellowish liquid, thickened wall and severe diffuse congestion in the mucosa.

Intestine: Presence of a whitish modulation of irregular edge, firm consistency of $1.7 \mathrm{~cm}$ in diameter over the jejunum serosa. Bloody catarrhal content in the duodenum and jejunum, yellowish in the ileum and pasty green in the colon and rectum, thickened walls with the formation of transverse folds, reactive Peyer plates.

Liver: Severe congestion.

Pancreas: No apparent changes.

Kidney: Severe congestion, whitish areas of radiated appearance in the cortex.

Brain: Moderate congestion.

Samples were taken during the necropsy for a histopathological study.

The most important results of the histopathological study were the following:

Lung: Newly formed cells are observed that originate from the epithelium of the bronchial tubes and bronchioles that accommodate forming packages or plates of cells separated by discrete connective tissue fibers. The neoplastic cells fill their own lamia and displace all other structures, respecting only the cartilage plates. Neoplastic cells leave the bronchus and invade the pulmonary alveoli, filling their lumen. 
Tumor cells are small, hyperchromatic, round to oval nucleus, very few show nucleoli, the amount of cytoplasm is poor and the number of mitosis per field is 1 .

Bowel: moderate to severe diffuse catarrhal enteritis with lymphoplasmocytic infiltration in the lamina propria. A cut presents invasion of tumor cells in serous, muscular and submucosa. deplasion.

Spleen: diffuse severe splenic lymphoid

Kidney: hydropic degeneration of some renal tubules, swollen glomeruli.

Lymph nodes: some lymph nodes have invasion (metastasis) of lung tumor cells.

Brain: cloudy degeneration and necrosis of some brain neurons.

\section{Diagnosis}

Based on the microscopic characteristics of the newly formed tissue and according to the classification of lung tumors of the Fifth Edition of the book "Tumors in Domestic Animals" it is concluded that the lung tumor found in the Doberman canine reason for the case, corresponds to a neoplasm called "neuroendocrine or carcinoid tumor".

\section{Discussion}

The case discussion will mainly focus on how the classification of this lung tumor has changed since 1974 to date. In 1974 the World Health Organization published a Bulletin in the form of a book called "International Histological Classification of Tumors of Domestic Animals" in which a grouping and classification of tumors of domestic animals is offered (WHO, 1974). In this bulletin, a so-called "anaplastic carcinoma" appears in the classification of lung tumors, which is divided into A) Anaplastic small cell carcinoma with three subdivisions 1. Lymphocyte-like type (oat cell carcinoma), 2. Fusiform type and 3. Polygonal type and B) Anaplastic large cell carcinoma. Due to its characteristics, the tumor discussed here would be classified as anaplastic small cell fusiform cell carcinoma.
In 1990 in the third edition of the book "Tumors in Domestic Animals" the tumor in question would be classified as "Anaplastic small cell carcinoma", but in this book this tumor is no longer subdivided; but division continues with anaplastic large cell carcinoma. In 2002, the fourth edition of the book "Tumors in Domestic Animals" disappeared the term "anaplastic carcinoma" and separated as independent tumors, leaving the classification as small cell carcinoma and large cell carcinoma.

With this classification our tumor in question would fall within the classification of small cell carcinoma, without any subdivision. In 2017, the fifth edition of "Tumors in Domestic Animals" appears in this edition the small cell carcinoma disappears, being included in the classification of "Neuroendocrine or carcinoid tumor". In all bibliographies it is mentioned that this tumor is very rare and that in humans it is very common in smokers. The above is very important since the canine that suffered the tumor would be considered as a passive smoker, because the owner smoked in the presence of the dog, exposed to all cigar chemicals and with a high probability of suffering from lung cancer.

In this same bibliography and as of 1974 the carcinoid already appears as a tumor independent of anaplastic small cell carcinoma. The carcinoid disappears in 1990 in the third edition of Tumor in Domestic Animals; but it reappears in the fourth edition and remains in the fifth edition of 2017.

\section{Conclusions}

Small cell lung tumors have undergone numerous changes in their classification and are currently classified as neuroendocrine or carcinoid tumors.

The 1974 classification (anaplastic small cell fusiform cell carcinoma) is the one that fully adapts to the description of the tumor found in the canber doberman under study; but the changes over the years make it currently classified as a neuroendocrine tumor. 


\section{References}

Choi U.S., Alleman A.R., Choi J.H., Kim H.W., Youn H.J., Lee C.W. 2008. Cytologic and immunohistochemical characterization of a lung carcinoid in a dog. Vet Clin. Pathol 37(2):249252.

D.Costa S., Yoon B.I., Kim D.Y., MotsingerReif A.A., Williams M., Kim Y. 2012. Morfological and molecular analysis of 39 spontaneous feline pulmonary carciomas. Vet. Pathol. 49(6):971-978.

Harkema J.R., Jones S.E., Naydan D.K., Wilson D.W. 1992. An atypical neuroendocrine tumor in the lung of a beagle dog. Vet. Pathol. 29(2):175-179.

Moulton J. E. Tumors of the Respiratory Tract. 1990. Pp. 319-336 in Tumors in Domestic Animals. Moulton J. E. $3^{\text {th }}$ ed. University of California Press. Berkeley, Los Angeles, London.

Ogilvie G.K., Haschek W.M., Winthrow S.J., Richardson R.C., Harvey H.J. Henderson R.A., Fowler J.D., Norris A.M., Tomlinson J., McCaw D. 1989. Classification of primary lung tumors in dogs: 210 cases (1975-1985). J. Am. Vet. Med. Assoc. 195(1):106-108.

Taylor G. N., Shabestari L., Williams J., Mays W., Angus W., McFarland S. 1976. Mammary neoplasia in a closed beagle colony. Cancer Research. 36(8):2040-2043.

Wilson D. W. 2017. Tumors of the Respiratory Tract. Pp. 480-489 in Tumors in Domestic Animals. Meuten D. J. $5^{\text {th }}$ ed. John Wiley and Sons Inc.

Wilson D. W. and Doungworth D. L. 2002. Tumors of the Respiratory Tract. Pp. 380-392 in Tumors in Domestic Animals. D. J. Meuten. $4^{\text {th }}$ ed. Blackwell Publishing.

World Health Organization. 1974. International Histological Classification of Tumours of Domestic Animals. Vol. 50, No. 1-2, pp. 9-19. 